\title{
ANTIBACTERIAL AND ANTIFUNGAL ACTIVITIES OF OCIMUM GRATISSIMUM L.
}

\author{
SANDEEP PANDEY \\ Centre for Botany, School of Environmental Biology, A. P. S. University, Rewa, 486003, M. P., India \\ Email: sandeep27pandey@rediffmail.com
}

Received: 19 Sep 2017 Revised and Accepted: 02 Nov 2017

\begin{abstract}
The development of antibiotic resistance in microorganisms is a global challenge for the clinicians, pharmacist and research scientists leading to the development of new medicinal formulations that are effective and easily consumable. The plant yielding essential oil with chief constituent as eugenol has been identified as an important compound with strong inhibition of bacteria, and storage fungi. Ocimum gratissimum is an aromatic shrub occurring in warm tropical regions has been used in traditional medicine in India to cure various ailments in general and as an antimicrobial agent in particular. The literature surveyed reveals that the plant oil exhibit strong potentiality against gram negative and gram positive bacteria along with diverse human and plant fungi. As a natural product, the plant oil is safer as food preservatives and stored grain protectant and has wide application in cosmetics and perfumery industries. This comprehensive review is attempted to provide the valuable information on antimicrobial activities of the plant essential oil that will be used to explore and develop a standard therapeutics system for the management of clinical and multiple drug resistant microorganisms.
\end{abstract}

Keywords: Ocimum gratissimum, Essential oil, Antibacterial, Antifungal

(C) 2017 The Authors. Published by Innovare Academic Sciences Pvt Ltd. This is an open access article under the CC BY license (http://creativecommons.org/licenses/by/4.0/) DOI: http://dx.doi.org/10.22159/ijpps.2017v9i12.22678

\section{INTRODUCTION}

Multiple drug resistance (MDR) and synthetic food-a great concern to human health

The rise in antibiotic-resistant microbes in last five decades or more has emerged as a big crisis and a serious threat in every region of the world [1]. The increasing ineffectiveness in the antibiotic activities used for controlling plant and animal pathogen [2-4] has become a big challenge among researchers, clinicians and policymakers. Antimicrobial synthetic products used in food industries are even not safer as for the human health is concerned, leading to chemical toxicity [5]. Although the new science of molecular-microbial interaction helps in understanding and resolving the antibiotic-resistant complex mechanism, but the more success lies in discovery of new medicines to control infections in this twenty-first century resistance era [1] and also to provide valuable information on medicinal plant, their parts used and methods of preparation for treating various diseases [6]. Altogether these and many more allied issues have drawn curiosity in searching for a new drug formulation $[7,8]$ that are safer as food preservative [5] and can control diseases and food contamination caused by microbial activities.

\section{Plant essential oil-an alternative to MDR microbes}

The plant essential oils (EO) complex mixtures of mono-and sesquiterpenoids with hundreds of constituents [9] derived as secondary metabolites from aromatic and other higher plants [4, 10-11] can be a better alternative in protecting from infections and combating antimicrobial drug-resistant (ADR) pathogens [8]. Natural products have no or fewer side effects $[12,13]$ compared to synthetic chemicals that are blended with food products [13]. In recent years, scientific research has focused more in discovering and identifying local plant species with bioactive compounds as an essential oil, their characterization extraction and purification processes and application in drug industries [14]. Presently 25 to $50 \%$ of drugs are available from plants [15] and numerous other aromatic plants are under evaluation for their valuable essential oil [13]. The traditional use of plant essential oil in folk medicine, fragrance, food flavouring and preventing food spoilage and their antimicrobial activities in plant and animal models is well documented [4, 16-17]. Most important thing that the researchers insisted is in restoring the bioactive compounds of essential oils by combining them with other products (like antibiotics), for generating synergistic actions of the obtained products $[9,18-19]$.

Ocimum gratissimum-exploring potentiality as an essential oil yielding plant in tropics

Ocimum gratissimum L. commonly known as clove basil belonging to family Lamiaceae is an important aromatic and medicinal plant existing wild or cultivated in various tropical and subtropical parts of the globe. The plant possesses two unique features firstly it contains essential oil with diversity in chemical composition and water stress tolerance capacity. Plant oil is considered the Mother Nature's chemical factory [20] shows a unique composition of alcohols, aldehydes, ketones, ethers, esters, lactones, oxides, peroxides [21], tannins [22] and flavonoids [23]. The plant obtained from various regions in Africa mainly contain eugenol, thymol, methyl eugenol, camphor, (Cis)-ocimene, (trans)ocimene, $\beta$-pinene, gramicidin $\mathrm{D}$, (trans)-caryophyllene, $\Gamma$-terpinene and p-cymene [24-26]. Brazilian and Asian races contain phenylephrine (eugenol) as the chief constituent [27-29] along with sesquiterpene (caryophyllene), monoterpenes ( $\beta$-ocimene) [25], bornyl acetate and some non terpene components [30]. There is scientific evidence about the eugenol which is a hydroxy phenylpropene possessing significant antimicrobial activity against bacteria and fungi mainly human pathogens, multi-drug resistant and food spoilage microorganism [31] Moreover, plant flavonoids and tannins which are an important constituent of 0 . gratissimum, possess unique antibacterial activities against the plant and human bacterial pathogens as reported in earlier studies either in the same or other plants oil [32-34].

The studies related to the efficacy of essential oil of Ocimum gratissimum against gram-negative [25-28], gram-positive bacteria [25-26, 35], fungi $[30,36]$, and its regular consumption as spice without affecting the activities of conventional antibiotics [37], makes it a strong antimicrobial herbal product throughout the tropics.

Moreover, the plant shows drought tolerant capacity without undergoing any change in cell structure and composition, thus making it another strong candidate along with other plants to combat drought conditions [38]. The use of plant volatile oil in inhibiting microorganism of economic importance is well approved and justified in the literature. This systematic review is attempted to explore the antimicrobial potentiality of clove basil oil for wide application in food and drug industries. 


\section{Antimicrobial activities of Ocimum gratissimum}

The aromatic properties of 0 . gratissimum and their use for various ailments dates long back in the ancient past history is mentioned in great Indian Medicinal epic 'Charaka Samhita', 'Sushruta Samhita' [39] and 'Materia Indica' [40]. Different mechanism has been applied to test the efficacy of plant oil to inhibit microbes in vitro and in vivo.

\section{Antibacterial activities of Ocimum gratissimum}

The essential oil (EO) of the plant shows a high range of antibacterial activity against animal and human pathogenic gram positive and gram negative bacteria (table 1). The essential oil expresses strong inhibitory action against oral swab bacteria $K$ pneumonia and $P$. vulgaris, thus proving effective mouthwashes [41].

According to a study, the plant oil was found effective against human pathogenic Staphylococcus aureus (Rosenbach) causing skin infection and Staphylococcus choleraesuis (Smith) causing food infection and nonpathogenic Bacillus subtilis (Ehrenberg) Cohn with the minimal inhibitory concentration (MIC) value 1, 1.10 and $0.60 \mathrm{mg} / \mathrm{ml}$ respectively [42]. The plant extract is a good anti-diarrheal agent showing a remarkable inhibition of E. coli [43-44], Shigella $s p$. and Salmonella sp [43] Salmonella enteritidis [26], Shigella flexineri [25, 28] Salmonella typhi, Shigella dysenteriae, Aeromonas sobria, and Plesiomonas shigelloides, with strongest action against $S$. dysenteriae [44].

Table 1: Antimicrobial activities of 0 . gratissimum oil against bacteria and fungi

\begin{tabular}{|c|c|c|}
\hline \multicolumn{2}{|c|}{ Microbes } & \multirow[t]{2}{*}{ Sources } \\
\hline A. & Bacteria & \\
\hline i. & Gram Negative & \\
\hline 1. & Staphylococcus choleraesuis & [26] \\
\hline 2. & Escherichia coli & {$[19,25-26,43-48,51,53-56]$} \\
\hline 3. & Aeromonas sobria & [44] \\
\hline 4. & S. typhi & {$[25,50-51]$} \\
\hline 5. & S. marcescens & [28] \\
\hline 6. & P. aeruginosae & [25] \\
\hline 7. & P. mirabilis & {$[25,47]$} \\
\hline 8. & K. pneumonia & {$[25,41,49]$} \\
\hline 9. & Klebsiella sp. & [26] \\
\hline 10. & Shigella sp. & {$[43,46,83]$} \\
\hline 11. & S. dysenteriae & [44] \\
\hline 12. & Plesiomonas shigelloides & [44] \\
\hline 13. & Shigella flexineri & {$[26,29]$} \\
\hline 14. & Salmonella sp. & {$[43,46]$} \\
\hline 15. & Salmonella enteritidis & {$[2,26]$} \\
\hline 16. & Salmonella typhimurium & {$[51,54]$} \\
\hline 17. & Salmonella enterica & [25] \\
\hline 18. & Pseudomonas aeruginosa & {$[47,56]$} \\
\hline 19. & Proteus vulgaris & {$[26,41]$} \\
\hline 20. & Vibrio cholerae & [49] \\
\hline ii. & Gram-Positive & \\
\hline 1. & Enterococcus faecium & [42] \\
\hline 2. & Enterococcus faecalis & [48] \\
\hline 3. & Staphylococcus aureus & {$[19,25,42,46-47,50-51,53-54,57-58,84]$} \\
\hline 4. & Bacillus subtilis & {$[42,48]$} \\
\hline 5. & Bacillus sp. & [25] \\
\hline 6. & Bacillus cereus & [29] \\
\hline 7. & Listeria monocytogenes & {$[25,31,58]$} \\
\hline 8. & Listeria innocua & [58] \\
\hline 9. & Streptococcus faecalis & {$[42,56]$} \\
\hline 10. & Streptococcus agalactiae & [86] \\
\hline B. & Fungi & \\
\hline i. & Human pathogenic fungi & \\
\hline 1. & Basidiobolus haptosporus & {$[61]$} \\
\hline 2. & B. ranarum & [61] \\
\hline 3. & Trichophyton rubrum & [61] \\
\hline 4. & T. mentagrophytes & [61] \\
\hline 5. & Tinea versicolor & [60] \\
\hline 6. & Candida albicans & {$[25,47,54,62-64]$} \\
\hline 7. & C. krusei & {$[57,63]$} \\
\hline 8. & C. parapsilosis & [63-64] \\
\hline 9. & C. tropicalis & [63] \\
\hline 10. & Cryptococcus neoformans & {$[62,64-65]$} \\
\hline 11. & Aspergillus flavus, & [64] \\
\hline 12. & A. fumigatus & [64] \\
\hline 13. & A. niger & [64] \\
\hline 14. & Microsporum canis & [66] \\
\hline 15. & M. gypseum & [19] \\
\hline 16. & Trichophyton rubrum & [19] \\
\hline 17. & T. mentagrophytes & [19] \\
\hline ii. & Plant pathogenic fungi & \\
\hline 1. & Rhizoctonia sp. & [69] \\
\hline 2. & R. Solani & [67] \\
\hline 3. & Botryosphaeria rhodina & [69] \\
\hline
\end{tabular}




\begin{tabular}{|c|c|c|}
\hline 4. & Penicillium chrysogenum & [69] \\
\hline 5. & Alternaria sp. & [69] \\
\hline 6. & Alternaria padwickii & [36] \\
\hline 7. & Bipolaris oryzae & [36] \\
\hline 8. & P. citrinum & [71] \\
\hline 9. & C. sphaerospermum & [71] \\
\hline 10. & Aspergillus flavus & {$[58,70]$} \\
\hline 11. & A. niger & {$[48,70]$} \\
\hline 12. & A. ochraceus & [70] \\
\hline 13. & A. parasiticus & [70] \\
\hline 14. & A. fumigatus & [58] \\
\hline 15. & Fusarium solani & [70] \\
\hline 16. & F. moniliforme & [75] \\
\hline 17. & F. verticillioides & [72-73] \\
\hline 18. & F. oxysporum & {$[68,70]$} \\
\hline 19. & F. graminearum & [70] \\
\hline 20. & Mucor spp & [70] \\
\hline 21. & Sclerotium rolfsii & [74] \\
\hline iii. & Food contamination fungi & \\
\hline 1. & Aspergillus spp & [78] \\
\hline 2. & A. flavus & [76] \\
\hline 3. & A. ochraceus & [77] \\
\hline 4. & Penicillium spp & [78] \\
\hline 5. & Penicillium expansum & {$[77,82]$} \\
\hline 6. & P. verrucosum & [77] \\
\hline 7. & Fusarium spp & [78] \\
\hline 8. & Scopulariopsis spp & [78] \\
\hline
\end{tabular}

There are studies that supported this hot water and ethanol leaf extracts inhibiting Staphylococcus aureus [45-46], E. coli, Salmonella sp. and Shigella sp. [46] whereas other work supported metabolic leaf extract showing inhibitory action against E. coli [47-48], Bacillus subtilis [48], $S$. aureus, P. aeruginosa and P. mirabilis [47]. The inhibition of $E$. coli and $B$. subtilis bacterial isolates using ethyl acetate extract of $O$. gratissimum was also reported [48]. Another study justifies aerial parts of the hexane fraction of the plant having antidiarrheal activity against $V$. cholera [49]. Some observation reported aqueous extracts suppressing $S$. typhi strains with $\mathrm{MBC}$ and MIC values of 55 and $40 \mathrm{mcg} / \mathrm{ml}$ [50]. Various other observations found that the essential oil processed through steam distillation expresses high inhibition of $S$. aureus, E. coli, S. typhimurium and $S$ typhi [51], or even obtained through hydro-distillation shows strong efficacy against Bacillus sp. S. typhi, P. aeruginosae, P. mirabilis, $K$. pneumonia [25,52] along with $S$. aureus and E. coli [25,52-54], $S$. typhimurium [54], Salmonella enteritidis [2] and also restrict extracellular protease enzyme kinetics of $E$. Coli [55].

o. gratissimum essential oil was reported to exhibits significant inhibition of organisms that cause urinary tract infections (UTI) as evidenced in various studies. The result shows that essential oil possesses strong action against UTI Serratia marcescens [28] Enterococcus faecium [42], Escherichia coli, Staphylococcus aureus, Proteus mirabilis, Klebsiella sp. which may be credited to the presence of eugenol [26]. Some report proposes that the hexane fraction of the aerial parts of the plant shows antibacterial action against $K$. pneumoniae causing pneumonia and UTI [49] whereas another study illustrates methanolic plant extract being most effective against Enterococcus faecalis [48]. The strong inhibitory action of ethanolic leaf extract of the plant against UTI Staphylococcus faecalis, Escherichia coli and Pseudomonas aeruginosa was also reported [56]. The time of collection of plant parts and flowering shows a significant impact on disease curing process. Plant oil collected during a pre-flowering stage at 7 am shows high activity against $S$. aureus with MIC $0.24 \mathrm{mg} / \mathrm{ml}$ [57]. The concentration-dependent plant oil exhibit strong antibacterial action against food contaminating Bacillus cereus [29] and ethanolic leaves extract in $250 \mathrm{mg} / \mathrm{ml}$ of plant oil proved best in inhibiting food borne pathogenic bacteria Listeria monocytogenes [31]. Similar results were also obtained by other studies that exhibit an effective inhibition of Salmonella enterica [30], L. monocytogenes [25, 58], along with two other bacterial strains Listeria innocua and S. aureus [58]. Further, the observation discloses that L. innocua stained with carboxyfluorescein diacetate had a decline in fluorescence intensity (FI) of cells exposed to plant oil compares to unexposed cells [58].

\section{Antifungal activities of Ocimum gratissimum}

\section{Human pathogens}

o. gratissimum essential oil exhibits an effective fungicidal activity against a wide range of human fungal pathogens as evidenced in various literatures (table 1). Plant oil with five chemotypes is very common folk medicine and among this ethyl cinnamate is very popular Indian chemotype with antifungal activities [59]. Dried or fresh plant samples are utilized to treat superficial mycosis in young children with strong anti-dermatophyte activity against infected scalp and hand [60]. The plant extract has potentiality in suppressing the growth of Basidiobolus haptosporus, B. ranarum, causing subcutaneous infection in children below ten years, along with Trichophyton rubrum and T. mentagrophytes that cause skin, feet and fingernail infections in human [61].

Literature survey discloses that essential oil shows potent antifungal properties. There are various studies providing evidence of the use of plant oil in inhibiting Candida albicans the causal organism of skin infection in humans $[54,62-64]$ and Aspergillus molds including $A$. flavus, A. fumigatus and A. niger [64]. The methanolic [47] and in some cases hydro-distilled leaf extract was also found effective against this fungus $[25,52]$. A study suggests that plant oil has potentiality in suppressing other groups of Candida genus like $C$. parapsilosis $[63,64], C$. krusei and C. tropicalis providing a shield to HIV patients against candidiasis infection [63]. The crude plant oil $[62,64]$ and even the eugenol and chloroform fraction of crude extracts of plant exhibit an effective action against Cryptococcus neoformans isolate that causes central nervous and lung disorders, showing potentiality in protecting AIDS patients against Cryptococcal infection [65]. According to another study, the hexane fraction and eugenol extract of the plant leaf at a concentration of 125-micron $\mathrm{ml} \mathrm{(-1)}$ suppresses $100 \%$ and $80 \%$ growth of dermatophytes Microsporum gypseum, M. canis, Trichophyton mentagrophytes and T. rubrum [66].

\section{Plant pathogens}

O. gratissimum essential oil is a strong antifungal agent against plant pathogens as proved in various studies. As a natural product, they can be utilized to the management of a variety of pests in vegetable, cereals and stored grains. Several studies observed that plant oil exhibit a remarkable inhibition of $A$. niger causal organism of black 
mold in vegetable and fruit [45], $R$. Solani, a soil-borne plant pathogenic fungus [67] and $F$. oxysporum f. sp lycopersici and eight other phytopathogenic fungi [68]. The ethanolic extract of aerial parts of the plant provides evidence of suppressing plant pathogens, Rhizoctonia sp., Botryosphaeria rhodina and two strains of Alternaria $s p$. (Alternaria sp. (A1) and Alternaria sp. (A2)-tomato wilt fungi) which are mainly due to the presence of eugenol a phenolic compound with fungitoxic properties. Further, this eugenol tested for anti-fungal action expresses significant control of Alternaria sp. (A1) and Penicillium chrysogenum [69]. The fresh leaves oil expresses strong efficacy against mycoflora Aspergillus flavus, A. niger, A. ochraceus, A. parasiticus, Fusarium solani, F. oxysporum, F. graminearum and Mucor $s p$ with a minimal fungicidal concentration ranging between 5.5 to $8.0 \mu \mathrm{l} / \mathrm{ml}$ [70], while other study supported methanolic leaf extract being effective against A. niger [48]. The plant extract can act as a promising fungitoxic agent against molds $P$. citrinum and mycoflora $C$. sphaerospermum [71], whereas the plant essential oil shows remarkable inhibition of Alternaria padwickii and Bipolaris oryzae, the seed-borne fungi of rice, remaining active even up to six days of storage [36]. The plant oil with eugenol as the main ingredient exhibits a strong anti-fungal action against $F$. verticillioides $[72,73]$ and also suppresses fumonisin contamination level in closed conditions in Maize [73]. O. gratissimum leaf ash shows strong potentiality in inhibiting germination of Sclerotium rolfsii, a soil-borne facultative pathogen in wheat [74].

Plant oil has shown promising inhibitory action against three food spoilage and mycotoxin fungi, F. moniliforme, Aspergillus fumigatus and A. flavus and remains stable even in changing $\mathrm{pH}$ environment hence making it an important food preservative [75]. A study reported that the plant oil possess shelf life enhancer property and can act as an anti-aflatoxigenic agent against aflatoxin and fungal contamination of spices with the potentiality to restrict aflatoxin B1(AFB1) formation of A. flavus [76]. The volatile oil also exhibits an effective food preservation property as reflected by various researchers. The $\mathrm{pH}$ and concentration-dependent study conducted on fungicidal activity of EO on mycotoxigenic strains each from $P$. expansum, $A$. ochraceus and $P$. verrucosum reveals a strong activity against these strains [77] The investigation on efficacies of six essential oils against Aspergillus, Penicillium, Fusarium and Scopulariopsis genera for preservation of cheese wagashi reported 0 . gratissimum as the second best essentials oil in suppressing these molds [78].

\section{Synergistic properties of essential oil in combination with other products}

The characteristic feature of the clove basil essential oil to freeze the activity of microorganism that developed resistance against the antibiotic drug should be exploited in discovering new formulations in which the sovereignty of the natural product and highly influential antibiotics should be sustained. In this context, various studies are undertaken focusing on developing a blended product with more synergism. The combination of clove basil volatile oil with antibiotics [79] and other biologically active substances shows an effective synergism resulting strong therapeutic potentiality of the product. In traditional practice, it is reported that a combination of honey and clove basil oil results in a highly synergetic product that possesses a strong wound healing capacity in humans [80]. Plant oil possesses the anti-sceptical property and with hydrophilic bases exhibits an effective antibacterial action against pimples, boil and wound [81]. Another research reports that the mixture of various fractions of plant essential oil against two strains of fungus Penicillium expansum MRC 6935 and MRC 6939, the causal organism of the rotting of vegetables and fruits (like apples), reported that the obtained product shows strong synergistic effects against strain MRC 6935 with 0.77 NDRcfu (Number of Decimal Reduction of colony forming units). This effect can be used in enhancing the antimicrobial action of essential oil slowing down the concentrations of the oil required in producing an antimicrobial effect without impact on the edible product [82].

According to a study, the combination of antibiotics fluoroquinolones and $O$. gratissimum oil forms an efficient synergistic anti-diarrheal product against Shigella bacteria that causes diarrhea in humans [83]. The hexane extracts of the plant in combination with norfloxacin enhance and modifies activities of antibiotics against multiresistant strains of bacteria S. aureus [84]. Plant oil and eugenol combined with antibiotics amikacin and erythromycin were deemed to be synergetic against $E$. coli and $S$. aureus. Further, this combination with antibiotic Gentamicin also develops a synergetic product with high efficacy against these microorganisms [85]. Combination of eugenol with biologically produced silver nanoparticles of Fusarium oxysporum (AgNPbio) exhibited a strong synergistic action against Streptococcus agalactiae a bacteria present in maternal vaginal causing infection in infants [86]. Nefang, a polyherbal anti-malarial folklore medicine of Cameroon of which 0 . gratissimum leaves are a major constituent exhibit an excellent in vitro action against multi-drug resistant Plasmodium falciparum along with in vivo suppression of $P$. berghei and P. chabaudi malaria parasites [87].

\section{CONCLUSION}

In conclusion, 0 . gratissimum essential oil is a boon for producing novel drugs and food preservatives with antimicrobial activities. They are worth in combating antibiotic resistant bacteria and fungal pathogens. As a safe natural product, they are a better substitute for synthetic drugs and are highly recommended for food, fragrance and pharmaceutical industries. In the present situation, the emphasis should be given more to discover antimicrobial elements from plant oil for developing effective medicines that can nullify the effect of antibiotic-resistant microbes. Moreover, the focus should be developing new blended products by combining antibiotics or other organic compounds with the clove basil oil which shows unique synergistic property with wide applications in medicines and food industries.

\section{CONFLICT OF INTERESTS}

\section{Declared none}

\section{REFERENCES}

1. Brown ED, Wright GD. Antibacterial drug discovery in the resistance era. Nature 2016;529:336-43

2. Adeola SA, Folorunso OS, Okedeyi OO, Ogungbe BF, Babatimehin OB, Thanni OZ. Antioxidant and antimicrobial activities of the volatile oil of Ocimum gratissimum and its inhibition on partially purified and characterized extracellular protease of Salmonella enteritidis. Am J Drug Dis Dev 2014;4:180-93.

3. Mohammadpour N, Emami SA, Asili J. Identification of volatile oil components of Nepeta binaludensis Jamzad by GC-MS and ${ }^{13} \mathrm{C}$-NMR methods and evaluation of its antimicrobial activity. J Essent Oil-Bear Plants 2013;16:102-7.

4. Shukla S, Hegde S, Kumar A, Chaudhary G, Tewari SK, Upreti DK, et al. Chemical composition and antibacterial activity of essential oil from leaves of Justicia adhatoda against methicillian resistant and sensitive strain along with their clinical isolates. J Essent Oil-Bear Plants 2017;20:116-22.

5. Hossain MA, Kabir MJ, Salehuddin SM, Rahman SMM, Das AK, Singha SK, et al. Antibacterial properties of essential oils and methanol extracts of sweet basil Ocimum basilicum occurring in Bangladesh. Pharm Biol 2010;48:504-11.

6. Kumar S, Pandey S. An ethnobotanical study of local plants and their medicinal importance in Tons river area, Dehradun, Uttarakhand. Indian J Trop Biodiversity 2015;23:227-31.

7. Maryam I, Huzaifa U, Hindatu H, Zubaida S. Nanoencapsulation of essential oils with enhanced antimicrobial activity: a new way of combating antimicrobial Resistance. J Pharma Phytochem 2015;4:165-70.

8. Vadhana P, Singh BR, Bharadwaj M, Singh SV. The emergence of herbal antimicrobial drug resistance in clinical bacterial isolates. Pharm Anal Acta 2015;6:434.

9. Tak Jun-Hyung, Isman MB. Penetration-enhancement underlies synergy of plant essential oil terpenoids as insecticides in the cabbage looper, Trichoplusiani. Sci Rep 2017;7:424-32.

10. Swamy MK, Akhtar MS, Sinniah UR. Antimicrobial properties of plant essential oils against human pathogens and their mode of action: an updated review. J Evidence-Based Complementary Altern Med 2016. http://dx.doi.org/10.1155/2016/3012462 
11. George M, Britto SJ. Phytochemical, antioxidant and antibacterial studies on the leaf extracts of curcuma amada Roxb. Int J Curr Pharm Res 2016;8:32-8.

12. Tyagi R, Sharma G, Jasuja ND, Menghani E. Indian medicinal plants as an effective antimicrobial agent. J Crit Rev 2016;3:69-71.

13. Hu Qing-Ping, Cao Xin-Ming, Hao Dong-Lin, Zhang, Liang-Liang Chemical composition, antioxidant, DNA damage protective, cytotoxic and antibacterial activities of Cyperus rotundus rhizomes essential oil against foodborne pathogens. Sci Rep 2017;7:45231.

14. Osuntokun OT, Ogunleye AJ. Prospects of essential oils in drug discovery. Adv Cytol Pathol 2017;2:00010.

15. Cowan MM. Plant products as antimicrobial agents. Clin Microbiol Rev 1999;12:564-82.

16. Kalemba D, Kunicka A. Antibacterial and antifungal properties of essential oils. Curr Med Chem 2003;10:813-29.

17. Sharifi-Rad J, Sureda A, Tenore GC, Daglia M, Sharifi-Rad M, Valussi M, et al. Biological activities of essential oils: from plant chemoecology to traditional healing systems. Molecules 2017;22:70.

18. Yap PSX, Yiap BC, Ping HC, Lim SHE. Essential oils, a new horizon in combating bacterial antibiotic resistance. Open Microbiol J 2014;8:6-14.

19. Silva VA, da Sousa JP, Pessôa HDF, de Freitas AFR, Coutinho HDM, Alves LBN, et al. Ocimum basilicum: antibacterial activity and association study with antibiotics against bacteria of clinical importance. Pharm Biol 2016;54:863-7.

20. Laurence BH. Labiatae oils-mother nature's chemical factory. $\mathrm{XI}^{\text {th }}$ Intial Congr. Essent. Oils, Fragrances-and Flavours. New Delhi; 1989.

21. Svendsen AB, Scheffer JJC. Isolation and analysis of essential oils. In: Verghese J. Essential-Oils. Synthite, Kolenchery, India; 1986.

22. Alexander P. Phytochemical screening and mineral composition of the leaves of Ocimum gratissimum (Scent leaf). Int J Appl Sci Biotechnol 2016;4:161-5.

23. Macdonald IO, Oludare AS, Olabiyi A. Phytotoxic and antimicrobial activities of flavonoids in Ocimum gratissimum. Life Sci J 2010;7:45-8.

24. Koba K, Sanda K, Guyon C, Raynaud C, Millet J, Chaumont JP, et al. chemical composition and in vitro cytotoxic activity of essential oils from two tropical Lamiaceae: Aeollanthus pubescens Benth and Ocimum gratissimum L. J Essent Oil Bear Plants 2007;10:60-9.

25. Matasyoh LG, Matasyoh JC, Wachira FN, Kinyua MG, Thairu MAW, Mukiama TK. Antimicrobial activity of essential oils of Ocimum Gratissimum L. from different populations of Kenya. Afr J Tradit Complementary Altern Med 2008;5:187-93.

26. Mith $\mathrm{H}$, Yayi-Ladékan E, Kpoviessi SDS, Bokossa IY, Moudachirou M, Daube G, et al. Chemical composition and antimicrobial activity of essential oils of Ocimum basilicum, Ocimum canum and Ocimum gratissimum in function of harvesting time. J Essent Oil Bear Plants 2016;19:1413-25.

27. Nakamura CV, Ueda-Nakamura T, Bando E, Melo AFN, Cortez DAG, Dias F, et al. Antibacterial activity of Ocimum gratissimum L. essential oil. Memdo Inst Oswaldo Cruz 1999;94:675-8.

28. Joshi RK. Chemical composition, in vitro antimicrobial and antioxidant activities of the essential oils of Ocimum gratissimum, O. Sanctum and their major Constituents. Indian J Pharm Sci 2013;75:457-62.

29. Singh P, Jayaramaiah RH, Agawane SB, Vannuruswamy G, Korwar AM, Anand A, et al. Potential dual role of eugenol in inhibiting advanced glycation end products in diabetes: proteomic and mechanistic insights. Sci Rep 2016;6:18798.

30. Katara A, Pradhan CK, Singh P, Singh V, Ali M. Volatile constituents and antimicrobial activity of aerial parts of Ocimum gratissimum Linn. J Essent Oil Bear Plants 2013;16:283-8.

31. Marchese A, Ramona B, Erika C, Ilkay EO, Maria D, Seyed FN, et al. Antimicrobial activity of eugenol and essential oils containing eugenol: a mechanistic viewpoint. Crit Rev Microbiol 2017;43:668-89.

32. Pradeepa M, Kalidas V, Geetha N. Qualitative and quantitative phytochemical analysis and bactericidal activity of Pelargonium graveolens L'Her. Int J Appl Pharm 2016;8:7-11.
33. Hemalatha S, Akther T, Khan MS. Extraction of flavonoid from various parts of Couroupita guianensis and its efficacy against pathogenic bacteria. Asian J Pharm Clin Res 2017;10:354-8.

34. Pandey S, Shukla A, Pandey S, Pandey A. Morphology, chemical composition and therapeutic potential of Somlata (Sarcostemma acidum Wight and Arn.). Pharma Sci Monit 2017;8:54-60.

35. Mbata T, Saikia A. Antibacterial activity and phytochemical screening of crude ethanolic extract of leaves of Ocimum gratissimum L on listeria monocytogenes. Internet J Microbiol 2007;4:1-6.

36. Nguefack J, Nguikwie SK, Fotio D, Dongmo B, Amvam Zollo PH, Leth $\mathrm{V}$, et al. Fungicidal potential of essential oils and fractions from Cymbopogon ainsliecitratus, Ocimum gratissimum and Thymus vulgaris to control Alternaria padwickii and Bipolaris oryzae, two seed-borne fungi of rice (Oryza sativa L.). J Essent Oil Res 2007;19:581-7.

37. Nweze EI, Eze EE. The justification for the use of Ocimum gratissimum L in herbal medicine and its interaction with disc antibiotics. BMC Complementary Altern Med 2009;9:37.

38. Pandey S, Shukla A, Pandey S, Pandey A. An overview of resurrecting herb 'Sanjeevani' (Selaginella bryopteris) and its pharmacological and ethnomedicinal uses. J Pharm Innovation 2017;6:11-4.

39. Gulabkunverha. Charaka samhita: an English, Hindi and Gujarati translation. Jamnagar (India): Shree Gulabkunerba Ayurvedic Society; 1949.

40. Ainslie W. Materia Indica. Vol. 1. London: Longman Rees Orme Brown and Green; 1826.

41. Ahonkhai I, Ba A, Edogun O, Mu U. Antimicrobial activities of the volatile oils of Ocimum bacilicum L. and Ocimum gratissimum L. (Lamiaceae) against some aerobic dental isolates. Pak J Pharm Sci 2009;22:405-9.

42. Sartoratto A, Machado ALM, Delarmelina C, Figueira GM, Duarte MCT, Rehder VLG. Composition and antimicrobial activity of essential oils from aromatic plants used in Brazil. Braz J Microbiol 2004;35:275-80.

43. Olamide SO, Agu GC. The assessment of the antimicrobial activities of Ocimum gratissimum (Wild Basil) and Vernonia Amygdalina (Bitter Leaf) on some enteric pathogen causing dysentery or diarrhea in patients. Int J Eng Sci 2013;2:83-96.

44. Ilori M, Sheteolu AO, Omonigbehin EA, Adeneye AA. Antidiarrhoeal activities of Ocimum gratissimum (Lamiaceae). J Diarrhoeal Dis Res 1996;14:283-5.

45. Akinyemi KO, Oladapo O, Okwara CE, Ibe CC, Fasure KA Screening of crude extracts of six medicinal plants used in South-West Nigerian unorthodox medicine for anti-methicillin resistant Staphylococcus aureus activity. BMC Complementary Altern Med 2005;5:6.

46. Amengialue 00, Edobor 0, Egharevba AP. Antibacterial activity of extracts of Ocimum gratissimum on bacteria associated with diarrhea. Bayero J Pure Appl Sci 2013;6:143-5.

47. Okechukwu OI, Tahir F. Phytochemical and antimicrobial screening of the leaf extract of Ocimum gratissimum L. J Econ Taxon Bot 2008;32:171-7.

48. Mishra RP, Javed I. In vitro activity of medicinal plants against some bacterial and fungal isolates. Asian J Pharm Clin Res 2015;8:225-30.

49. Mann A. Phytochemical constituents and antimicrobial and grain protectant activities of clove basil (Ocimum gratissimum L.) grown in Nigeria. Int J Plant Res 2012;2:51-8.

50. Akinyemi KO, Mendie UE, Smith ST, Oyefolu AO, Coker AO. Screening of some medicinal plants used in south-west Nigerian traditional medicine for anti-Salmonella typhi activity. J Herb Pharmacother 2005;5:45-60.

51. Adebolu TT, Oladimeji SA. Antimicrobial activity of leaf extracts of Ocimum gratissimum on selected diarrhoea causing bacteria in southwestern Nigeria. Afr J Biotech 2005;4:682-4.

52. Matasyoh LG, Matasyoh JC, Wachira FN, Kinyua MG, Thairu MAW, Mukiama TK. Chemical composition and antimicrobial activity of the essential oil of Ocimum gratissimum L. growing in Eastern Kenya. Afr J Biotech 2007;6:760-5.

53. Ishiwu CN, Umenwanne CP, Obiegbuna JE, Uchegbu NN. In vitro assessment of the anti bacterial effect of extracts of Ocimum 
Gratissimum and Carica Papaya leaves. Int J Appl Sci Technol 2014;4:171-7.

54. Sharma SM, Bhadange DG. Antimicrobial potential of lamiaceae members. Int J Pharm Sci 2013;3:324-7.

55. Adesegun AS, Samuel FO, Anthony OB, Nurudeen OA. Antioxidant and inhibitory properties of essential oil of Ocimum gratissimum against extracellular protease of Escherichia Coli. Iosr J Pharm 2013;3:50-5.

56. Stanley MC, Ifeanyi OE, Chinedum OK, Chinenye ND. The antibacterial activity of leaf extracts of Ocimum gratissimum and Sida acuta. Int J Microbiol Res 2014;5:124-9.

57. Kpadonou KBG, Ladekan EY, Kpoviessi DS, Gbaguidi $\mathrm{F}$, Yehouenou B, Quetin-Leclercq J, et al. Chemical variation of essential oil constituents of Ocimum gratissimum L. from Benin, and impact on antimicrobial properties and toxicity against Artemia salina leach. Chem Biodivers 2012;9:139-50.

58. Nguefack J, Budde BB, Jakobsen M. Five essential oils from aromatic plants of Cameroon: their antibacterial activity and ability to permeabilize the cytoplasmic membrane of Listeria innocua examined by flow cytometry. Lett Appl Microbiol 2004:39:395-400.

59. Dubey NK, Tiwari TN, Mandin D, Andriamboavonjy H, Chaumont Jean-Pierre. Antifungal properties of Ocimum gratissimum essential oil (ethyl cinnamate chemotype). Fitoterapia 2000;71:567-9.

60. Obot MJ, Aluyi HAS. Treatment of superficial mycoses with Ocimum gratissimum. Int J Infect Dis 2002;6:151.

61. Nwosu MO, Okafor JI. Preliminary studies of the antifungal activities of some medicinal plants against basidiobolus and some other pathogenic fungi. Mycoses 1995;38:191-5.

62. Braga FG, Lúcia $M$, Bouzada $M$, Fabri RL, deOMatos $M$, Moreira FO, et al. Antileishmanial and antifungal activity of plants used in traditional medicine in Brazil. J Ethnopharmacol 2007;111:396-402.

63. Nakamura CV, Ishida K, Faccin LC, Filho BPD, Diógenes AG, Cortez DAG, et al. In vitro activity of essential oil from Ocimum gratissimum L. against four Candida species. Res Microbiol 2004; $155: 579-86$

64. Fokou JBH, Dongmo PMJ, Boyom FF, Menkem EZ, Bakargna-Via I, Tsague IFK, et al. Antioxidant and antifungal activities of the essential oils of Ocimum gratissimum from Yaoundé and Dschang (Cameroon). J Pharm Pharmacol 2014;2:257-68.

65. Lemos JdeA, Passos XS, Fernandes OdeFL, de Paula JR, Ferri $\mathrm{PH}$, Souza LKH, et al. Antifungal activity from Ocimum gratissimum L. towards Cryptococcus neoformans. Mem Inst Oswaldo Cruz 2005;100:55-8.

66. Silva MR, Oliveira JGJr, Fernandes OF, Passos XS, Costa CR, Souza LK, et al. Antifungal activity of Ocimum gratissimum towards dermatophytes. Mycoses 2005;48:172-5.

67. Sethi S, Prakash O, Chandra M, Punetha H, Pant AK. Antifungal activity of essential oils of some Ocimum species collected from different locations of Uttarakhand. Indian J Nat Prod Resour 2013;4:392-7.

68. Mohr FBM, Lermen C, Gazim ZC, Gonçalves JE, Alberton 0. Antifungal activity, yield, and composition of Ocimum gratissimum essential oil. Genet Mol Res 2017;16. Doi:10.4238/gmr16019542.

69. Faria TdeJ, Ferreira RS, Yassumoto L, de Souza JRP, Ishikawa NK, Barbosa AdeM. Antifungal activity of essential oil isolated from Ocimum gratissimum L. (eugenol chemotype) against phytopathogenic fungi. Braz Arch Biol Technol 2006;49:867-71.

70. Adjou ES, Kouton S, Dahouenon-Ahoussi E, Mohamed M, Soumanou MM, Sohounhloue DCK. Effect of essential oil from fresh leaves of Ocimum gratissimum L. on mycoflora during storage of peanuts in Benin. Mycotoxin Res 2013;29:29-38.

71. Bankole SA, Somorin YM. Antifungal activity of extracts of Ocimum gratissimum and Aframomum danielli against molds isolated from stored rice. $10^{\text {th }}$ International Working Conference on Stored Product Protection. ed. Julius-KühnArchiv; 2010. p. 425.
72. Dambolena JS, Zunino MP, López AG, Rubinstein HR, Zygadlo JA, Mwangi JW, et al. Essential oils composition of Ocimum basilicum L. and Ocimum gratissimum L. from Kenya and their inhibitory effects on growth and fumonisin production by Fusarium verticillioides. Innovative Food Sci Emerging Technol 2010;11:410-4

73. Fandohan P, Gbenou JD, Gnonlonfin B, Hell K, Marasas WF, Wingfield MJ. Effect of essential oils on the growth of Fusarium verticillioides and fumonisin contamination in corn. J Agric Food Chem 2004;52:6824-9.

74. Enikuomehin OA, Ikotun T, Ekpo EJ. Evaluation of ash from some tropical plants of Nigeria for the control of sclerotium rolfsii Sacc on wheat (Triticum aestivum L.). Mycopathologia 1998;142:81-7.

75. Nguefack J, Leth V, Amvam Zollo PH, Mathur SB. Evaluation of five essential oils from aromatic plants of cameroon for controlling food spoilage and mycotoxin-producing fungi. Int J Food Microbiol 2004;94:329-34.

76. Prakash B, Shukla R, Singh P, Mishra PK, Dubey NK, Kharwar RN. Efficacy of chemically characterized Ocimum gratissimum L. essential oil as an antioxidant and a safe plant based antimicrobial against fungal and aflatoxin B1 contamination of spices. Food Res Int 2011;44:385-90.

77. Nguefack J, Dongmo JBL, Dakole CD, Leth V, Vismer HF, Torp J, et al. Food preservative potential of essential oils and fractions from Cymbopogon citratus, Ocimum gratissimum and Thymus vulgaris against mycotoxigenic fungi. Int J Food Microbiol 2009;131:151-6.

78. Sessou P, Farougou S, Ahounou S, Hounnankpon Y, Azokpota P, Youssao I, et al. Comparative study of antifungal activities of six selected essential oils against fungal isolates from cheese wagashi in Benin. Pak J Biol Sci 2013;16:1751-7.

79. Jedlickova Z, Mottl O, Sery V. Antibacterial properties of the Vietnamese cajeput oil and ocimum oil in combination with antibacterial agents. J Hyg Epidemiol Microbiol Immunol 1992;3:303-9.

80. Orafidiya LO, Adesina JrSK, Igbeneghu OA, Akinkunmi EO, Adetogun GE, Salau AO. The effect of honey and surfactant type on the antibacterial properties of the leaf essential oil of Ocimum gratissimum Linn. against common wound-infecting organisms. Int J Aromather 2006;16:57-62.

81. Orafidiya LO, Oyedele AO, Shittu AO, Elujoba AA. The formulation of an effective topical antibacterial product containing Ocimum gratissimum leaf essential oil. Int J Pharm 2001;(1, Suppl 2):177-83.

82. Nguefack J, Tamgue O, Lekagne Dongmo JB, Dakole C, Leth $\mathrm{V}$, Vismer $\mathrm{H}$, et al. Synergistic action between fractions of essential oils from Cymbopogon citratus, Ocimum gratissimum and Thymus vulgaris against Penicillium expansum. Food Control 2012;23:377-83.

83. Iwalokun BA, Gbenle GO, Adewole TA, Smith SI, Akinsinde $\mathrm{KA}$, Omonigbehin EO. Effects of Ocimum gratissimum L essential oil at subinhibitory concentrations on virulent and multidrug-resistant Shigella strains from Lagos, Nigeria. APMIS 2003;111:477-82.

84. Coutinho HD, Matias EF, Santos KK, Santos FA, Morais-Braga MF, Souza TM, et al. Modulation of the norfloxacin resistance in Staphylococcus aureus by Croton campestris A. and Ocimum gratissimum L. Biomedica 2011;31:608-12.

85. Silva MKdoN, Carvalho VRDeA, Matias EFF. Chemical profile of essential oil of Ocimum gratissimum L. and evaluation of antibacterial and drug resistance-modifying activity by gaseous contact method. Pharmacogn J 2016;8:4-9.

86. Biasi-Garbin RP, Otaguiri ES, Morey AT, da Silva MF, Morguette AEB, Lancheros CAC. Effect of eugenol against Streptococcus agalactiae and synergistic interaction with biologically produced silver nanoparticles. Evid Based Complementary Alternat Med 2015. http://dx.doi.org/10.1155/2015/861497.

87. Arrey TP, Okalebo FA, Ayong LS, Agbor GA, Guantai AN. Antimalarial activity of a polyherbal product (Nefang) during early and established Plasmodium infection in rodent models. Malaria J 2014;13:456. 